\title{
Fertility Status of Soils at the Teaching and Research Farm of Akwa Ibom State University, Obio Akpa Campus, Southeast Nigeria
}

\author{
U. J. Ekong ${ }^{1}$, I. G. Uduak ${ }^{2}$ \\ Department of Soil Science, Akwa lbom State University
}

\begin{abstract}
A study was conducted to assess the fertility status of soils at the Teaching and Research Farm of Akwa Ibom State University, Obio Akpa Campus, Akwa Ibom State, Nigeria. Results obtained from analysis of ten composite surface soil samples (0-30 cm depth) from fifteen sampling points each per composite sample, revealed that the soils were largely loamy sand in texture, very strongly acidic ( $\mathrm{pH} 5.2$ - 5.4) and have high organic matter content (4.68 - $4.90 \%)$. The electrical conductivity (EC) of the soils ranged from 0.051 to $0.055 \mathrm{dSm}^{-1}$, which was low with the mean value of $0.053 \mathrm{dSm}^{-1}$. The values of the total $\mathrm{N}$ content $(0.10-0.12 \%)$ and available $P(4.70-5.18 \mathrm{mg} / \mathrm{kg})$ were low. The exchangeable Ca, Na and $\mathrm{K}$ were low, the values ranged from $3.20-3.50 \mathrm{cmol} / \mathrm{kg}, 0.06-$ $0.07 \mathrm{cmol} / \mathrm{kg}$ and $0.03-0.15 \mathrm{cmol} / \mathrm{kg}$ respectively. The exchangeable Mg ranged from $1.40-1.60 \mathrm{cmol} / \mathrm{kg}$, which was at a high level. The effective cation exchange capacity of the soils ranged from $6.79-7.31 \mathrm{cmol} / \mathrm{kg}$ and it was low, while the base saturation ranged from 69.01 to $71.87 \%$ which was at a high level, indicating availability of basic cations. The available micronutrients: $\mathrm{Fe}$, Cu, Mn, Zn and $B$ values ranged from $169.14-177.40 \mathrm{mg} / \mathrm{kg}, 1.30-1.70 \mathrm{mg} / \mathrm{kg}, 2.18-2.48 \mathrm{mg} / \mathrm{kg}, 5.08-5.88 \mathrm{mg} / \mathrm{kg} \mathrm{and} 0.55-0.67 \mathrm{mg} / \mathrm{kg}$ respectively. Available $\mathrm{Fe}$ was high, followed by $\mathrm{Zn}, \mathrm{Mn}, \mathrm{Cu}$ and $\mathrm{B}$. The soils were low in fertility and would require the use of fertilizers (organic and inorganic), cover crops to protect the soil surface against soil erosion and adequate use of lime to achieve the benefits of fertilizer application for sustainable crop production.
\end{abstract}

Keywords: Fertility status, coastal plain sands, management.

\section{Introduction}

Food production in the tropics has faced serious challenges over the years due to decline in soil quality. The adoption of more efficient farming practices and technologies that enhance agricultural production and improve environmental sustainability remains the most practical option for achieving economic growth, food security and poverty alleviation in Africa (Ersador et. al., 2004). Soil quality in relation to food production is anchored on how the fertility of soils is being managed. Soil quality is defined as the capacity of a specific soil to function, within natural or managed ecosystem boundaries, to sustain plant and animal productivity, maintain or enhance water and air quality, and support human health and habitation (Brady and Weil, 1999). Soil fertility therefore, is the capacity of the soil to supply nutrients that enhance crop growth and ensure sustainable food production. However, soils are exposed to one form of disturbance or the other. The associated problems culminate to soil degradation which depicts a loss in the quality or productivity of soils. Degradation is attributed to changes in soil nutrient status, loss of organic matter, deterioration of soil structure, and toxicity due to accumulations of naturally occurring or anthropogenic materials.

Depending on their inherent characteristics and the climate, soils vary from highly resistant, or stable, to those that are vulnerable and extremely sensitive to degradation. The economic impact of soil degradation is extremely severe in densely populated regions, and sub-Sahara Africa. The productivity of some soils in Africa has declined by $50 \%$ as a result of soil erosion and desertification. Yield reduction in Africa (Lal, 1990) due to past soil erosion may range from 2 to $40 \%$, with a mean loss of $8.2 \%$ for the continent. If accelerated erosion continues unabated, yield reduction by 2020 may be as high as $16.5 \%$.

It is in the context of these global economic impacts of soil degradation, and numerous functions of value to humans, that soil degradation and resilience concepts are relevant (Eswaran, 1993). As soil resources are essentially nonrenewable, it is necessary to adopt a positive approach to sustainable management of these finite resources. To achieve this, accelerated and sustainable agricultural intensification is required (Oram et. al., 1979). However, intensification, increased agricultural productivity and improved rural livelihoods cannot occur without investment in soil fertility (Place et. al., 2003).

In recent times, emphasis is on proper management of the soil resource base, restoration of degraded soils, and halting the decline trend in agricultural production. This is predicated on the study of soil properties and characterization of soils and farming systems in a particular area.

Akwa Ibom State is one of the major food producing areas in the southern part of Nigeria. Some of the soils, including those of the Akwa Ibom State University Teaching and Research Farm, have little been studied. This paper reports a study of the physico-chemical properties and management practices that will ensure optimum crop yields on the soils of the University Farm.

\section{Materials and Methods}

\section{Characterization of the Study Area}

The study area, University Teaching and Research Farm, Obio Akpa Campus is situated between latitude $4^{\circ} 30^{\prime} \mathrm{N}$ and 


\section{International Journal of Science and Research (IJSR) \\ ISSN (Online): 2319-7064}

Index Copernicus Value (2013): 6.14 | Impact Factor (2014): 5.611

$5^{\circ} 30^{\prime} \mathrm{N}$ and longitude $7^{\circ} 30^{\prime} \mathrm{E}$ and $8^{\circ} 00^{\prime} \mathrm{E}$ of the Greenwich Meridian (SLUS-AK, 1989).

The area is in the humid tropical region, characterized by two seasons; rainy and dry. The dry season spans from November - March while the rainy season is experience from April - October. There is a short dry spell in August otherwise called 'August break'. The Monsoon air mass blowing over the Atlantic Ocean sweeps through this zone resulting in heavy annual rainfall of $2000-2500 \mathrm{~mm}$ in the wet season. The annual temperature range is $24^{\circ} \mathrm{C}-30^{\circ} \mathrm{C}$ and the annual relative humidity range of $75-79 \%$ (SLUS-AK, 1989). The soil of this area is formed from the coastal plain sands parent materials and is classified as an Ultisols based on the USDA system of classification (Soil Survey Staff, 1999). The vegetation of the area was originally tropical rainforest but is now predominantly secondary forest.

\section{Field and Laboratory study}

Ten composite surface soil samples (0 - $30 \mathrm{~cm}$ depth) were randomly taken from fifteen locations per composite sample selected to represent the entire Teaching and Research Farm. The samples were carefully labelled and package in polythene bags for laboratory analysis. The soil samples were air dried, ground and passed through a $2 \mathrm{~mm}$ sieve to remove materials greater than $2 \mathrm{~mm}$ in diameter. The sieved samples were subjected to particle size analysis which was determined by the Bouyoucos hydrometer method as outlined by Jackson (1969), using calgon (sodium hexametaphosphate) as a dispersing agent. Soil $\mathrm{pH}$ was determined in a 1:2.5 soil/water ratio in suspension using a glass electrode $\mathrm{pH}$ meter. Organic carbon was determined by the Walkley and Black wet oxidation method. The values of organic carbon were multiplied by a Vanbameller factor of 1.724 to obtain values for organic matter. Electrical conductivity (EC) was determined using conductivity bridge by dipping the electrode into the soil-water suspension (Hanna, 1964). Total nitrogen was determined by the modified macro-kjeldahl method of Bremner (1965). Available phosphorus was extracted by the Bray 1 extraction method (Bray and Kurtz, 1945), and the content of P was determined colorimetrically. Determination of exchangeable bases was by neutral Ammonium acetate extraction and read with an Atomic Absorption Spectrophotometer (AAS). Exchangeable acidity was determined by the $1 \mathrm{~N} \mathrm{KCl}$ extraction method (McLean, 1965) and titrated with $1 \mathrm{M}$ sodium hydroxide $(\mathrm{NaOH})$ using phenolphthalein as an indicator. The effective cation exchange capacity (ECEC) was obtained as the summation of the total exchangeable bases and exchangeable acidity. Percentage base saturation (\% BS) was obtained by calculation using the formula:

\section{$\% \mathrm{BS}=\underline{\text { sum of exchangeable bases }} \times 100$ ECEC}

\section{Results and Discussion}

\section{Particle Size Distribution}

The particle size distribution of the soil is shown in Table 1. Sand fraction was the dominant mechanical particle, followed by clay and silt. The sand fraction ranged from $80.40 \%$ to $88.80 \%$ and averaged $85.30 \%$. The silt fraction of the soil ranged from $2.00 \%$ to $8.70 \%$, averaged $4.40 \%$, while the clay fraction ranged from $5.70 \%$ to $15.60 \%$ with the mean value of $10.30 \%$. The soil texture was predominantly loamy sand and was in consonance with the research findings of Obi (2000) who stated that the percent clay in loamy sand soils was not greater than $30 \%$, less than $30 \%$ silt and greater than $80 \%$ sand, indicating a lower amount of fine soil particles consequent upon high infiltration rate, leaching losses and low water holding capacity culminating to nutrients deficiency.

\section{Chemical properties}

The chemical properties of the composite surface soil samples are shown in Table 2. The $\mathrm{pH}$ values of the soils ranged from 5.20 to 5.40 and averaged 5.30, indicating very strong acidity. The acidic nature of the soil could be attributed mostly to excessive leaching due to the high amount of rainfall of the area. This condition can lead to phosphate fixation and can also reduce the ability of microorganisms to fix atmospheric nitrogen. The acidic condition of the soil could be responsible for the levels of available phosphorus and total nitrogen. In acidic soils, phosphorus is fixed by active iron, aluminium and manganese compounds. There is need to reduce this level of acidity in order to improve soil fertility for sustainable crop production.

The surface soil recorded high levels of organic matter that ranged from 4.68 to $4.90 \%$ with an average value of $4.82 \%$. The high levels of organic matter may be due to luxuriant vegetation mainly of grasses and shrubs, and the slow rate of microbial decomposition of the vegetation. The soil organic matter content agrees with the report findings of Uduak et. al.,(2014) who gave values of organic matter to range from 2.46 to $4.97 \%$ for cross river floodplain soils. The high organic matter content contributes to soil tilth and nutrient holding capacity (Tisdale et. al., 1993). Electrical conductivity (EC) of the soil ranged from 0.051 to $0.055 \mathrm{dSm}^{-1}$ and averaged $0.053 \mathrm{dSm}^{-1}$. EC is a measure of total cations and anions in soil solution and is usually determined mainly by calcium and magnesium ions, depending on the soil type. Total nitrogen content ranged from $0.10-0.12 \%$ with the mean value of $0.11 \%$. The $\mathrm{N}$ content was low as values were below the critical limit of $0.15 \%$ (FMANR, 1999). The low level of total $\mathrm{N}$ could be attributed to leaching of nitrates due to excessive rainfall and plant removal. The low $\mathrm{N}$ status of the soil will have serious implications on the fertility of the soil, as crop plants need this nutrient in large quantity for growth. Available phosphorus content ranged from 4.70 to $5.18 \mathrm{mg} / \mathrm{kg}$ with the mean value of $5.00 \mathrm{mg} / \mathrm{kg}$, indicating low level of available $\mathrm{P}$ in the soil. The low level of available $\mathrm{P}$ in the soil was suspected to be due to strong acidic nature of the soil which invariably renders $\mathrm{P}$ unavailable. Exchangeable $\mathrm{Ca}, \mathrm{Mg}, \mathrm{Na}$ and $\mathrm{K}$ ranged from $3.20-3.50 \mathrm{cmol} / \mathrm{kg}, 1.40-1.60 \mathrm{cmol} / \mathrm{kg}$, $0.06-0.07 \mathrm{cmol} / \mathrm{kg}$ and $0.03-0.15 \mathrm{cmol} / \mathrm{kg}$ respectively with the mean values of $3.33 \mathrm{cmol} / \mathrm{kg}, 1.51 \mathrm{cmol} / \mathrm{kg}, 0.06$ $\mathrm{cmol} / \mathrm{kg}$ and $0.10 \mathrm{cmol} / \mathrm{kg}$ respectively. The exchangeable $\mathrm{Ca}$ content was at moderate value which was lower than 4 $\mathrm{cmol} / \mathrm{kg}$ regarded as the critical value for fertile soils (FAO, 1976). The exchangeable $\mathrm{Mg}$ content in the soil was at high level, the value recorded was above the critical value 0.50 $\mathrm{cmol} / \mathrm{kg}$ (FAO, 1976). Exchangeable sodium content was low just like exchangeable potassium which fell below the

\section{Volume 4 Issue 11, November 2015}




\section{International Journal of Science and Research (IJSR) \\ ISSN (Online): 2319-7064 \\ Index Copernicus Value (2013): 6.14 | Impact Factor (2014): 5.611}

critical level of $0.2 \mathrm{cmol} / \mathrm{kg}$ reported by Chude et. al.,(2011) for soils of humid tropical zone . Calcium and magnesium were the dominant exchangeable bases in decreasing amounts in the order $\mathrm{Ca}>\mathrm{Mg}>\mathrm{K}>\mathrm{Na}$, reflecting the decreasing energy of adsorption by clay complex. The effective cation exchange capacity (ECEC) ranged from 6.79 - $7.31 \mathrm{cmol} / \mathrm{kg}$ with the mean value $7.10 \mathrm{cmol} / \mathrm{kg}$. The values obtained were below the critical value $20 \mathrm{cmol} / \mathrm{kg}$ regarded to be suitable for crop production (FAO, 1976). The percent base saturation had it range from 69.01 - 71.87 $\%$ and a mean of $70.57 \%$. High values of base saturation could be attributed to the high levels of calcium and magnesium in the adsorption complex, indicating availability of some basic cations which are important indices of a fertile soil.

The available micronutrients of the ten composite surface soil samples are presented in Table 3. Fe, Cu, Mn, $\mathrm{Zn}$ and B ranged from $169.14-177.40 \mathrm{mg} / \mathrm{kg}, 1.30-1.70 \mathrm{mg} / \mathrm{kg}, 2.18$ - $2.48 \mathrm{mg} / \mathrm{kg}, 5.08-5.88 \mathrm{mg} / \mathrm{kg}$ and $0.55-0.67 \mathrm{mg} / \mathrm{kg}$ respectively and the mean values of $172.50 \mathrm{mg} / \mathrm{kg}, 1.44$ $\mathrm{mg} / \mathrm{kg}, \quad 2.33 \mathrm{mg} / \mathrm{kg}, \quad 5.51 \mathrm{mg} / \mathrm{kg}$ and $0.62 \mathrm{mg} / \mathrm{kg}$ respectively. Generally, the levels of available micronutrients were high (Ibia, 2012) compared with the critical level for $\mathrm{Mn}(1.0 \mathrm{mg} / \mathrm{kg}), \mathrm{Cu}(0.2 \mathrm{mg} / \mathrm{kg}), \mathrm{Zn}(0.5$ $\mathrm{mg} / \mathrm{kg})$ and $\mathrm{Fe}(4.5 \mathrm{mg} / \mathrm{kg})$. The available Mn contents of the soils were therefore high given the fact that all the values recorded were above $1.00 \mathrm{mg} / \mathrm{kg}$. Black (1968) stated that exchangeable Mn levels in soil between $1 \mathrm{mg} / \mathrm{kg}$ and 15 $\mathrm{mg} / \mathrm{kg}$ and above would be injurious to the growth of crop plants. Ibia (1995) opined that exchangeable $\mathrm{Zn}$ level in soil between $4.5 \mathrm{mg} / \mathrm{kg}$ and $10 \mathrm{mg} / \mathrm{kg}$ would be detrimental to the growth of crop plants. Fe having higher value than $\mathrm{Cu}$, $\mathrm{Mn}, \mathrm{Zn}$ and B is in line with the findings of Esu (2010) who attributed this to the abundance of sesquioxides in the humid tropical soils. The high contents of the micronutrients in the soils could be associated with acidity of the soils and poor drainage. There would likely be micronutrient (especially $\mathrm{Mn}$ and $\mathrm{Fe}$ ) toxicity if adequate liming were not done during cultivation. These metallic micronutrients usually form complex with other elements to enhance their availability to the growing crops and they are adequately supplied by organic manures (Udoh et. al., 2005). Therefore, the use of lime in combination with manure containing these trace elements is recommended for better yields. Excessive use of P-fertilizers creates the deficiency of some important micronutrients like $\mathrm{Fe}, \mathrm{Cu}$ and $\mathrm{Mn}$, which is traceable to the frequent use of chemical fertilizers on soils.

Based on FAO soil fertility evaluation standard (FAO, 1976) and FPDD rating of soil fertility based on soil testing values
(FPDD, 1989), all the soil types in Akwa Ibom State are rated low in fertility and will need adequate fertilizer applications to obtain high yields of arable crops. Optimum rate of fertilizers should be applied to crops. If the rate applied is below what is required, the optimal yield of crops will not be achieved. Excess application of fertilizer may lead to reduction in crop yield, poor quality of the crop, reduction in the availability of some nutrients, especially micronutrients and pollution of the surrounding environments, particularly water bodies near the affected area. Soil testing should be carried out before any fertilizer is applied. This should be done periodically to ensure that the right type and quantity is applied for the crops grown or about to be grown on the farm.

\section{Conclusion}

The physico-chemical properties of soils at the Teaching and Research Farm of Akwa Ibom State University, Obio Akpa Campus, Akwa Ibom State, Nigeria were investigated. Results revealed that the soils were strongly acidic and this acidity reduces the yields of crops even when fertilizers are applied to increase the fertility of the soils. An application of 0.5 ton/ha of lime is generally recommended for the humid tropical soils such as those found in the University farm. To increase crop yield in the study area, liming in combination with the application of organic manure to the soil will alter the $\mathrm{pH}$, increase the basic cations, organic matter, total nitrogen and rate of microbial decomposition of organic materials, therefore, improve the fertility status of the soil for sustainable crop production.

Table 1: Physical properties of soils at the Teaching and Research Farm of Akwa Ibom State University, Obio Akpa Campus

\begin{tabular}{|c|c|c|c|c|}
\hline \multirow[t]{2}{*}{ Location } & \multicolumn{3}{|c|}{$\begin{array}{c}\text { Particle size distribution } \\
(\%)\end{array}$} & \multirow[t]{2}{*}{ Textural Class } \\
\hline & Sand & Silt & Clay & \\
\hline 1 & 88.20 & 3.00 & 8.80 & Loamy sand \\
\hline 2 & 88.80 & 2.00 & 9.20 & Loamy sand \\
\hline 3 & 86.40 & 4.00 & 9.60 & Loamy sand \\
\hline 4 & 80.40 & 4.00 & 15.60 & Loamy sand \\
\hline 5 & 87.80 & 2.00 & 10.20 & Loamy sand \\
\hline 6 & 84.80 & 4.00 & 11.20 & Loamy sand \\
\hline 7 & 82.80 & 4.00 & 13.20 & Loamy sand \\
\hline 8 & 83.60 & 8.70 & 7.70 & Loamy sand \\
\hline 9 & 85.70 & 8.60 & 5.70 & Loamy sand \\
\hline 10 & 84.40 & 4.00 & 11.60 & Loamy sand \\
\hline Mean & 85.30 & 4.40 & 10.30 & \\
\hline
\end{tabular}




\section{International Journal of Science and Research (IJSR) \\ ISSN (Online): 2319-7064}

Index Copernicus Value (2013): 6.14 | Impact Factor (2014): 5.611

Table 2: Chemical properties of soils at the Teaching and Research Farm of Akwa Ibom State University, Obio Akpa Campus

\begin{tabular}{|c|c|c|c|c|c|c|c|c|c|c|c|c|}
\hline \multirow[t]{2}{*}{ Location } & \multirow[t]{2}{*}{$\begin{array}{l}\text { Soil pH } \\
\left(\mathrm{H}_{2} \mathrm{O}\right)\end{array}$} & \multirow[t]{2}{*}{$\begin{array}{l}\mathrm{O} . \mathrm{M} \\
(\%)\end{array}$} & \multirow[t]{2}{*}{$\begin{array}{c}\mathrm{EC} \\
(\mathrm{dS} / \mathrm{m})\end{array}$} & \multirow[t]{2}{*}{$\begin{array}{l}\text { Total N } \\
(\%)\end{array}$} & \multirow[t]{2}{*}{$\begin{array}{c}\text { Av. P } \\
(\mathrm{mg} / \mathrm{kg})\end{array}$} & \multicolumn{2}{|c|}{ Exch. Bases } & \multicolumn{3}{|c|}{$\begin{array}{l}\text { Exch. acidity } \\
(\mathrm{cmol} / \mathrm{kg})\end{array}$} & \multirow[t]{2}{*}{ ECEC } & \multirow[t]{2}{*}{$\begin{array}{l}\text { B.S } \\
(\%)\end{array}$} \\
\hline & & & & & & $\mathrm{Ca}$ & $\mathrm{Mg}$ & $\mathrm{Na}$ & $\mathbf{K}$ & $\left(\mathrm{H}^{+}+\mathrm{Al}^{3+}\right)$ & & \\
\hline 1 & 5.30 & 4.89 & 0.054 & 0.11 & 5.18 & 3.20 & 1.60 & 0.06 & 0.14 & 2.10 & 7.10 & 70.42 \\
\hline 2 & 5.20 & 4.83 & 0.055 & 0.12 & 4.72 & 3.30 & 1.50 & 0.06 & 0.14 & 1.99 & 6.99 & 71.53 \\
\hline 3 & 5.40 & 4.90 & 0.052 & 0.12 & 4.99 & 3.50 & 1.40 & 0.07 & 0.03 & 2.20 & 7.20 & 69.44 \\
\hline 4 & 5.20 & 4.77 & 0.055 & 0.10 & 5.16 & 3.30 & 1.40 & 0.06 & 0.04 & 1.99 & 6.79 & 70.69 \\
\hline 5 & 5.30 & 4.80 & 0.054 & 0.11 & 5.18 & 3.40 & 1.50 & 0.06 & 0.15 & 2.00 & 7.11 & 71.87 \\
\hline 6 & 5.30 & 4.70 & 0.054 & 0.12 & 4.70 & 3.20 & 1.60 & 0.07 & 0.03 & 2.20 & 7.10 & 69.01 \\
\hline 7 & 5.40 & 4.68 & 0.052 & 0.11 & 4.82 & 3.20 & 1.60 & 0.06 & 0.04 & 1.99 & 6.89 & 71.12 \\
\hline 8 & 5.40 & 4.83 & 0.052 & 0.11 & 4.90 & 3.30 & 1.60 & 0.06 & 0.14 & 2.20 & 7.30 & 69.86 \\
\hline 9 & 5.20 & 4.90 & 0.055 & 0.12 & 5.18 & 3.50 & 1.50 & 0.06 & 0.15 & 2.10 & 7.31 & 71.27 \\
\hline 10 & 5.20 & 4.90 & 0.051 & 0.12 & 5.16 & 3.40 & 1.40 & 0.06 & 0.15 & 2.10 & 7.11 & 70.46 \\
\hline Mean & 5.30 & 4.82 & 0.053 & 0.11 & 5.00 & 3.33 & 1.51 & 0.06 & 0.10 & 2.10 & 7.10 & 70.57 \\
\hline
\end{tabular}

Table 3: Available Micronutrients of soils at the Teaching and Research Farm of Akwa Ibom State University, Obio

\begin{tabular}{lccccc}
\multicolumn{7}{c}{ Akpa Campus } \\
\hline Location & \multicolumn{5}{c}{ Av. Micronutrients (mg/kg) } \\
& Fe & Cu & Mn & Zn & B \\
\hline 1 & 169.14 & 1.70 & 2.33 & 5.88 & 0.55 \\
2 & 170.33 & 1.30 & 2.48 & 5.08 & 0.67 \\
3 & 177.40 & 1.50 & 2.18 & 5.60 & 0.63 \\
4 & 170.30 & 1.40 & 2.46 & 5.08 & 0.57 \\
5 & 169.20 & 1.60 & 2.30 & 5.70 & 0.60 \\
6 & 174.15 & 1.30 & 2.46 & 5.68 & 0.62 \\
7 & 172.20 & 1.60 & 2.35 & 5.60 & 0.66 \\
8 & 175.08 & 1.40 & 2.20 & 5.08 & 0.58 \\
9 & 169.84 & 1.30 & 2.32 & 5.88 & 0.67 \\
10 & 177.33 & 1.30 & 2.18 & 5.56 & 0.63 \\
\hline Mean & $\mathbf{1 7 2 . 5 0}$ & $\mathbf{1 . 4 4}$ & $\mathbf{2 . 3 3}$ & $\mathbf{5 . 5 1}$ & $\mathbf{0 . 6 2}$ \\
\hline & & & & &
\end{tabular}

\section{References}

[1] Black, C. A (1968). Soil-Plant Relationship. John Wiley \& Sons Inc., New York, Pp. 792

[2] Brady, N. C. and Weil, R. R. (1999). The nature and properties of soils. $12^{\text {th }}$ ed., Prentice - Hall, New Jersey, $\quad$ Pp. $178-189$

[3] Bray, R. A. and L. T. Kurtz (1945). Determination of total and available forms of phosphorus in soils. Soil Science 53: 39 - 45

[4] Bremner, J. M. (1965). Total nitrogen in Methods of soil analysis part 2, 1149 - 1178, Madison, WC. American Society of Agronomy.

[5] Chude, V. O., S. O. Olayiwola, A. O. Osho and C. K. Daudu (2011). Fertilizer use and management practices for crops in Nigeria ( $4^{\text {th }}$ ed.). Federal Fertilizer Department, Federal Ministry of Agriculture and Rural Development, Abuja, 215 pp.

[6] Esu, I. E (2010). Soil characterization, classification and survey. HEBN Publishers Plc. Pp 23 - 40

[7] Ersado, L., Amacher, G. and Alwang, J., (2004). 'Productivity and Land-enhancing technologies in northern Ethiopia: Health, public Investments and sequential adoption', Amer. J. Agr. Econ. 86 (2): 321 331
[8] FAO (1976). A framework for land evaluation, FAO Soil Bulletin No. 32. FAO, Rome, 77pp.

[9] Federal Ministry of Agriculture and Natural Resources - FMANR (1999). Evolving an effective agricultural land use policy for Nigeria. $165 \mathrm{pp}$.

[10] FPDD (1989). Fertilizer use and management practices for crops in Nigeria. Federal Ministry of Agriculture, Water Resources and Rural Development. Lagos.

[11] Hanna, W. J. (1964). Chemistry of the soil. F. E. Bear (ed). Am. Chem.. soc. Monograph

[12] Ibia, T. O. (1995). Inland Swamps of Akwa Ibom State: Their Characteristics, Potentials and Constraints to Development. Paper presented at the $3^{\text {rd }}$ All African Soil Science Conference, University of Ibadan, Nigeria, August 19-26

[13] Ibia, T. O. (2012). Soil Chemistry, Soil Quality and National Development: The Nexus. $32^{\text {rd }}$ Inaugural Lecture Series, University of Uyo, Nigeria, May 31. Pp. 83

[14] Jackson, M. L. (1969). Soil Chemical analysis advanced course. $2^{\text {nd }}$ ed. Madison University of Wisconsin

[15] Lal, R. and B. Okigbo (1990). Assessment of Soil Degradation in the Southern States of Nigeria, Environment Department working paper No. 39; The World Bank, Washington, D.C

[16] McClean, E. O. (1965). Aluminium. In: C. A. Black (ed) Methods of Soil Analysis. Agronomy No 9 Part 2. American Society of Agronomy, Madison, Wisconsin, Pp978-998

[17] Obi, M. E. (2000). Soil Physics: A Compendium of Lectures. Nsukka, Nigeria. Pp 14

[18] Oram, P., J. Japata, G. Alibaruho and S. Roy. (1979). Investment and Input Requirements for Accelerating Food Production in Low-Income Countries by 1990. Research Report No. 10, IFPRI, Washington, D.C

[19] Place, F., C. B. Barett, H. A. Freeman, J. J. Ramisch and B. Vanlauwe (2003). 'Prospects for Integrated Soil Fertility management using organic and inorganic inputs: Evidence from smallholder African agricultural systems", Food policy, 28:365-378

[20] SLUS-AK (1989). Soils and Land Use Studies. Government print office, Uyo, Akwa Ibom State. Soil Survey Staff. 1994. Keys to Soil Taxonomy. Soil

\section{Volume 4 Issue 11, November 2015}




\section{International Journal of Science and Research (IJSR) \\ ISSN (Online): 2319-7064}

Index Copernicus Value (2013): 6.14 | Impact Factor (2014): 5.611

management support service (SMSS), Tech. Monogr.

No. 19. 306p

[21] Soil Survey Staff (1999). Soil Taxonomy. A basic system of soil classification for making and interpreting Soil Survey. ( $2^{\text {nd }}$ ed). USDA natural resources conservation service.

[22] Tisdale, S. L., W. L. Nelson, J. D. Beaton and J. L. Havlin (1993). Soil fertility and fertilizers. ( $\left.5^{\text {th }} \mathrm{ed}\right)$. Macmillan publ. Co., New York. 634pp

[23] Udoh, D. J., Ndon, B. A., Asuquo, P. E and N. U. Ndaeyo (2005). Crop Production Techniques for the Tropics. Concept publications, Lagos, pp 64-65

[24] Uduak, I. G; Akpan, E. A; Ekong, U. J; Ekwere, O. J and Enyong, J. K. (2014). Fertility Status and problems of Cross River floodplain soils. In: Proceedings of the $38^{\text {th }}$ Annual conference of Soil Science Society of Nigeria (SSSN). Pp 460-467 